\title{
Pernikahan Kekerabatan Bani Kamsidin (Studi Kasus Pernikahan Endogami Di Jawa Timur Tahun 1974-2015 M)
}

\author{
Siti Zya Ama \\ Mahasiswa Prodi Sejarah Dan Kebudayaan Islam UIN Sunan Kalijaga \\ Zyaama.azzahra.33@gmail.com
}

\begin{abstract}
Abstrak
Tradisi pernikahan kekerabatan Bani Kamsidin tidak umum terjadi jika dilihat dari sudut pandang ketentuan-ketentuan hukum dalam Islam dan norma serta adat yang berlaku di Indonesia pada umumnya. Keturunan Kamsidin yang sudah migran ke berbagai wilayah tetap memegang teguh tradisi pernikahan kekerabatan ini. Kemajuan pendidikan serta perkembangan zaman yang dialami keturunan Kamsidin tidak menyurutkan pernikahan ini untuk tidak bertahan. Oleh karena itu penulis tertarik mengkaji lebih lanjut bagaimana sejarah pernikahan Bani Kamsidin ini terjadi meliputi asal usulnya beserta prosesnya, motif-motifnya, dan perkembangan pernikahan Bani Kamsidin di Jawa Timur dari tahun 1974 sampai 2015 M. Metode penelitian yang digunakan adalah metode penelitian sejarah dengan melakukan beberapa tahap, yaitu tahap heuristik, verifikasi, interpretasi, dan historiografi. Hasil penulisan ini menunjukkan bahwa: pertama, pernikahan kekerabatan Bani Kamsidin bermula dari pesan Kamsidin kepada anak-anaknya untuk menikahkan anak-anaknya secara kekerabatan. Proses pernikahan kekerabatan Bani Kamsidin meliputi perjodohan, nyabek ocak, serpang, certacer, lamaran, ngalak sabek, akad nikah, resepsi pernikahan, ngirem, tongngebben, dan main ke ponduk. Kedua, perkembangan pernikahan kekerabatan Bani Kamsidin dapat diklasifikasikan ke dalam tiga periode, yaitu inti Bani Kamsidin, penyatuan keluarga, dan konflik. Ketiga, alasan Bani Kamsidin melakukan pernikahan kekerabatan adalah keyakinan agama, menjaga keturunan, dan menjaga keutuhan keluarga.
\end{abstract}

Kata Kunci: Pernikahan Kekerabatan; Bani Kamsidin.

\section{PENDAHULUAN}

Tradisi pernikahan kekerabatan Bani Kamsidin311 yang berkutat di dalam dan hanya berputar pada keturunan Kamsidin, tidak keluar dari keturunan orang lain, tidak umum terjadi jika dilihat dari sudut pandang ketentuan-ketentuan hukum dalam Islam dan norma serta adat yang berlaku di Indonesia pada umumnya. Di dalam Antropologi, salah satu sistem pernikahan yang berlandaskan hukum adat pada sebagian masyarakat Indonesia adalah sistem pernikahan

${ }^{1}$ Bani Kamsidin merupakan anak cucu atau keturunan Kamsidin dan istrinya, yaitu Sardimah. Kamsidin adalah nama yang dinisbahkan kepada sesepuh keturunan tersebut sebagai pencetus atau pelahir adanya perjodohan dan pernikahan kekerabatan pada keturunannya. 
endogami. Pernikahan endogami merupakan suatu sistem pernikahan yang harus dilakukan dengan memilih pasangan hidupnya yang berasal dari desa/ marga/ kasta/ keluarganya sendiri. ${ }^{2}$ Bani Kamsidin termasuk bagian dari masyarakat yang mempertahankan perkawinan adat endogami. Islam tidak pernah memberi keharusan adanya pernikahan dalam satu keturunan, sebaliknya Islam justru menganjurkan untuk saling mengenal antar keturunan.

Ditinjau dari sisi sosiologi, masyarakat Indonesia pada kenyataannya memandang bahwa pernikahan adalah fenomena penyatuan dua kelompok keluarga besar. Pernikahan menjadi sarana terbentuknya satu keluarga besar yang asalnya terdiri dari dua keluarga yang tidak saling mengenal, yakni satu dari kelompok (keluarga) suami (laki-laki) dan yang satunya dari keluarga istri (perempuan). ${ }^{3}$ Pandangan sosiologi tersebut berbeda dengan pernikahan yang terjadi pada Bani Kamsidin.

Karya Sahnun yang bermadzhab Maliki berjudul alMudawwanah, sebagaimana dikutip oleh Khoiruddin Nasution menjelaskan bahwa masalah kerelaan (al-rida) dari pasangan, khususnya calon istri, baik yang masih gadis maupun janda merupakan hal yang utama. ${ }^{4}$ UU No.1 Tahun 1974 pasal 6 ayat (1) juga menegaskan bahwa, "Perkawinan harus didasarkan atas persetujuan kedua calon mempelai". Demikian juga dalam Kompilasi Hukum Islam (KHI) pasal 17 ayat (2) menyatakan bahwa, "Bila ternyata perkawinan tidak disetujui oleh salah seorang calon mempelai maka perkawinan itu tidak dapat dilangsungkan". 5 Ketentuan-ketentuan yang telah dijelaskan di atas berbeda dengan ketentuan yang ada pada Bani Kamsidin. Pada Bani Kamsidin orang tualah yang memiliki kekuasaan penuh atas anak-anaknya. Jika orang tua dari calon pasangan sama-sama setuju maka pendapat anak tak memiliki pengaruh yang besar. Kamsidin juga memberikan pesan lain berupa syarat-syarat untuk ketursunannya yang hendak menikah dengan orang luar. ${ }^{6}$ hlm. 59.

2Sugeng Pujileksono, Pengantar Antropologi (Malang: Intrans Publishing, 2015),

${ }^{3}$ Khoiruddin Nasution, Hukum Perkawinan 1 (Yogyakarta: ACAdeMIA + TAZZAFA, 2005), hlm. 19.

${ }^{4}$ Ibid., hlm. 29-30.

5Ibid., hlm. 98.

${ }^{6}$ Orang luar berarti bukan keturunan Kamsidin dan tidak memiliki hubungan kekerabatan dengan Bani Kamsidin. 
Syarat-syarat tersebut berisi lima larangan yang harus dihindari keturunannya. Pertama, larangan menikah dengan anak haram atau hasil hubungan intim di luar nikah. Jika anak dari hubungan di luar nikah itu laki-laki, maka tujuh keturunan dari anak tersebut tidak boleh dinikahi oleh keturunan Kamsidin. Jika anak di luar nikah itu perempuan, maka tiga keturunan dari anak tersebut tidak boleh dinikahi oleh keturunan Kamsidin. Kedua, larangan menikah dengan anak dari keluarga atau nenek moyangnya ada yang melakukan bunuh diri. Ketiga, larangan menikah dengan anak dari keluarga atau nenek moyangnya ada yang gila. Keempat, larangan menikah dengan anak dari keluarga atau nenek moyangnya ada yang memiliki penyakit lepra, bahkan termasuk keponakannya. Kelima, larangan menikah dengan anak dari keluarga atau nenek moyangnya ada yang memiliki penyakit ayan. ${ }^{7}$ Menurut penulis syarat yang pertama, yaitu larangan menikah dengan anak haram berbeda dengan yang diajarkan Islam. Pada hadis riwayat Muslim dikatakan bahwa setiap anak dilahirkan dalam keadaan suci, jadi tidak sebutan anak haram.

Tradisi perjodohan dan pernikahan kekerabatan Bani Kamsidin ini sudah berlangsung sejak tahun 1974 dan masih dipertahankan oleh keturunannya sampai sekarang. Keturunan Kamsidin yang telah melakukan tradisi ini terbukti banyak yang berhasil, walaupun ada sebagian yang gagal ketika bertunangan, bahkan ada yang mengalami kegagalan pernikahan yang berakhir pada perceraian. Menurut keterangan dari keturunan Kamsidin yang penulis dapat bahwa pernikahan yang berhasil jauh lebih banyak daripada yang gagal. ${ }^{8}$

Selain itu terdapat sisi unik lain dari kondisi Bani Kamsidin yang sekarang tidak hanya bertempat tinggal di Desa Banjar Tabulu, Camplong, Sampang, Madura, tetapi juga banyak yang migran ke luar Madura seperti Surabaya, Pasuruan, Mojokerto, dan Jember tidak membuat pernikahan kekerabatan Bani Kamsidin menjadi tidak terlaksana. Tidak hanya itu, regenerasi Kamsidin yang sudah berbeda dengan keturunan-keturunan sebelumnya, yakni sudah mengikuti kemajuan pendidikan dan perkembangan zaman yang modern, masih tetap mempertahankan atau akan menjalankan pernikahan kekerabatan.

\footnotetext{
${ }^{7}$ Wawancara dengan Mujella, Saliman, Musallimun, dan Mulyati (keturunan Kamsidin dari garis Suki yang merupakan anak kedua Kamsidin) di Madura, tanggal 6 Juli 2016.

${ }^{8}$ Wawancara dengan Saliman (cucu Kamsidin dari anak yang ketiga yaitu Suki) melalui telepon di Jakarta, tanggal 16 Maret 2016.
} 
Berangkat dari latar belakang masalah di atas, penulis tertarik untuk mengkaji lebih lanjut bagaimanakah sebenarnya sejarah pernikahan kekerabatan Bani Kamsidin ini terjadi dan mengapa masih dipertahankan oleh Bani Kamsidin. Penulis menganggap perlu adanya sebuah rekaman sejarah dan nilai-nilai pesan yang terkandung dalam pernikahan kekerabatan yang terjadi dan masih dipertahankan oleh Bani Kamsidin di Jawa Timur.

Penelitian ini memfokuskan pada studi mengenai sejarah pernikahan kekerabatan yang secara khusus membahas mengenai pernikahan kekerabatan Bani Kamsidin. Sejauh ini sepengetahuan penulis belum ada hasil penelitian atau tulisan yang membahas tema tersebut. Tulisan-tulisan yang ada pada umumnya bersifat umum tentang pernikahan. Misalnya: Pertama, skripsi yang berjudul "Fenomena Pernikahan di Usia Muda di Kalangan Masyarakat Muslim Madura (Studi Kasus di Desa Bajur Kecamatan Waru Kabupaten Pamekasan)". Skripsi ini ditulis oleh Hairi Fakultas Ushuluddin, Jurusan Sosiologi Agama UIN Sunan Kalijaga pada tahun 2009.

Kedua, skripsi yang berjudul "Otonomi Perempuan Madura dalam Perkawinan (Studi Kasus di Desa Poteran Sumenep, Madura)". Skripsi ini ditulis oleh Miftahul Birri Fakultas Ushuluddin, Jurusan Aqidah dan Filsafat UIN Sunan Kalijaga pada tahun 2009. Ketiga, skripsi yang berjudul "Tradisi Perjodohan dalam Masyarakat Madura Migran di Kecamatan Depok, Sleman, Daerah Istimewa Yogyakarta". Skripsi ini ditulis oleh Rifi Hamdani Fakultas Ushuluddin dan Pemikiran Islam, Jurusan Perbandingan Agama UIN Sunan Kalijaga pada tahun 2013. Keempat, Skripsi yang berjudul "Nikah Muda di Kalangan Masyarakat Bujur Timur (Desa Bujur Timur, Kecamatan Batu Marmar, Kabupaten Pamekasan)". Skripsi ini ditulis oleh Ahmadi Idris Fakultas Ilmu Sosial dan Humaniora UIN Sunan Kalijaga pada tahun 2012.

Fokus penelitian ini adalah pernikahan kekerabatan Bani Kamsidin yang dilakukan secara endogami di Jawa Timur tahun 19742015. Tahun 1974 sebagai batas awal dari penelitian ini, karena pada tahun tersebut pernikahan kekerabatan Bani Kamsidin pertama kali dilaksanakan. Adapun tahun 2015 sebagai batas akhir dari penelitian ini, karena tahun tersebut merupakan pernikahan kekerabatan yang terakhir dilaksanakan untuk sementara ini. ${ }^{9}$ 
Pada mulanya Bani Kamsidin melakukan pernikahan endogami hanya dengan keluarganya sendiri. Namun demikian, pada perkembangannya pernikahan kekerabatan Bani Kamsidin mengalami perluasan endogami, yaitu melakukan pernikahan dengan keluarga yang memiliki hubungan kekerabatan dengan mereka. Untuk memudahkan pembahasan permasalahan yang dikaji dalam penelitian ini, dirumuskan masalah sebagai berikut:

1. Bagaimana asal usul dan proses pernikahan kekerabatan Bani Kamsidin?

2. Bagaimana perkembangan pernikahan kekerabatan Bani Kamsidin?

3. Apa motif-motif dan dampak pernikahan kekerabatan Bani Kamsidin?

Tahap-tahap metode penelitian sejarah dalam penelitian ini adalah sebagai berikut ${ }^{10}$

1. Heuristik (Pengumpulan Sumber)

2. Verifikasi (Kritik Sumber)

3. Interpretasi (Penafsiran)

4. Historiografi (Penulisan Sejarah

\section{HASIL DAN PEMBAHASAN}

Bani Kamsidin adalah istilah yang digunakan untuk menyebut anak cucu/ keturunan Kamsidin. Bani Kamsidin asal usulnya terdiri dari ketiga anak Kamsidin, yaitu Mujenib, Suki, dan Moh. Jailani yang melahirkan beberapa keturunan dan saat ini sudah berada digenerasi kelima dari Kamsidin. Awalnya Bani Kamsidin hanya bertempat tinggal di Desa Banjar Tabulu. Pada perkembangan selanjutnya anak cucu atau keturunan Kamsidin tidak hanya bertempat tinggal di Madura tetapi juga banyak yang migran. Ada yang migran di Surabaya, Mojokerto, Pasuruan, dan Jember.

Bani Kamsidin merupakan suatu keluarga besar yang terdiri dari beberapa keluarga yang melakukan pernikahan kekerabatan. Pernikahan kekerabatan mulai dijalankan setelah Kamsidin dan Sardimah memberikan pesan kepada anak-anaknya beserta menantumenantunya untuk menikahkan anak-anaknya secara kekerabatan 
atau anak dari anak-anaknya saling dinikahkan. ${ }^{11}$ Sepeninggal Kamsidin ${ }^{12}$ pernikahan kekerabatan selanjutnya dijalankan Sardimah dan anak-anaknya beserta menantu-menantunya. Oleh karena itu sampai saat ini Bani Kamsidin masih melakukan dan mempertahankan pernikahan kekerabatan karena masih dijaga secara turun temurun. Pada tahun 1974 pernikahan kekerabatan Bani Kamsidin pertama kali dilakukan, yaitu pernikahan Mujella dan Muwilah. ${ }^{13}$ Pernikahan yang sementara ini terakhir dilakukan adalah pernikahan Mushoffa dan Mujibah pada tahun 2015.14

Pendidikan Bani Kamsidin terbilang rendah. Umumnya mereka lulusan sekolah dasar (SD). Cucu-cucu Kamsidin hanya satu yang sekolah sampai Sekolah Menengah Atas (SMA), yaitu Muhammadun. Pada perkembangannya keturunan Kamsidin setelah generasi cucucucunya, banyak yang melanjutkan ke Sekolah Menengan Pertama (SMP) dan Sekolah Menengah Atas (SMA). Cicit Kamsidin yang melanjutkan ke Perguruan Tinggi (PT) baru dua orang, yaitu Imam Ghozali dan Siti Zya Ama.

Selain itu, kondisi perekonomian Bani Kamsidin adalah ratarata kelas menengah ke bawah. Keturunan Kamsidin yang dianggap lebih oleh penulis adalah Masriah (cucu Kamsidin dari anaknya yang kedua, yaitu Mujenib), Muhammadun (cucu Kamsidin dari anaknya yang ketiga, yaitu Suki), dan Abdul Qodir (cucu Kamsidin dari anaknya yang keempat, yaitu Moh. Jailani).

Kamsidin dan Sardimah juga memiliki syarat untuk keturunannya yang hendak menikah dengan orang luar. Syarat tersebut berisi lima larangan. Syarat yang diberikan Kamsidin kepada keturunannya, sampai kepada ketiga anaknya. Melalui Mujenib, Suki, dan Moh. Jailani syarat yang diberikan sampai pada keturunan

${ }^{11}$ Wawancara dengan Sum'a (istri Suki yang merupakan anak ketiga Kamsidin) melalui telepon di Madura, tanggal 30 Mei 2016.

${ }^{12}$ Kamsidin meninggal dunia jam 07.00 WIB, tanggal 19 bulan Tekepek tahun 1967, wawancara dengan Achmad Abdul Aziz melalui telepon di Madura, tanggal 11 oktober 2016 yang diambil dari buku catatan milik Kamsidin yang dibawa Achmad Abdul Aziz (cucu Kamsidin dari anak yang kedua yaitu Mujenib).

${ }^{13}$ Wawancara dengan Mujella di Madura (cucu Kamsidin dari anak yang ketiga yaitu Suki sekaligus pelaku pernikahan kekerabatan yang pertama), tanggal 1 Juli 2016.

${ }^{14}$ Wawancara dengan Muhwiyah di Madura (cucu Kamsidin dari anak yang keempat yaitu Moh. Jailani), tanggal 24 Agustus 2016. 
selanjutnya dan masih terjaga. ${ }^{15}$ Adapun syarat dari Kamsidin yang berisi lima larangan itu adalah sebagai berikut, 16

1. Larangan menikah dengan anak haram atau hasil hubungan intim di luar nikah. Jika anak dari hubungan di luar nikah itu laki-laki, maka tujuh keturunan ke bawah dari anak tersebut tidak boleh dinikahi oleh keturunan Kamsidin. Jika anak dari hubungan di luar nikah itu perempuan, maka tiga keturunan ke bawah dari anak tersebut tidak boleh dinikahi oleh keturunan Kamsidin.

2. Larangan menikah dengan anak dari keluarga atau nenek moyangnya ada yang melakukan bunuh diri.

3. Larangan menikah dengan anak dari keluarga atau nenek moyangnya ada yang gila.

4. Larangan menikah dengan anak dari keluarga atau nenek moyangnya ada yang memiliki penyakit lepra, bahkan termasuk keponakannya.

5. Larangan menikah dengan anak dari keluarga atau nenek moyangnya ada yang memiliki penyakit ayan.

Umumnya Bani Kamsidin melakukan pernikahan kekerabatan diawali dengan perjodohan dini dan akan dilaksanakan jika keturunan Kamsidin yang telah dijodohkan dianggap sudah dewasa dan siap menikah. Oleh karena itu, di dalam ruang waktu atau jarak yang ada terdapat proses pernikahan kekerabatan Bani Kamsidin adalah sebagai berikut: perjodohan, nyabek ocak, serpang, certacer, lamaran, ngalak sabek, akad nikah, resepsi pernikahan, ngirem, tongngebben, dan main ke ponduk.

Pernikahan kekerabatan Bani Kamsidin mengalami perkembangan sejak pertama kali dilakukan yaitu pada tahun $1974 \mathrm{M}$, sampai tahun 2015 M. Pernikahan kekerabatan sejauh ini masih dipertahankan oleh Bani Kamsidin karena adanya alasan/ dorongan yang menyebabkan mereka tetap melakukan pernikahan kekerabatan, seperti yang telah dijelaskan pada bab sebelumnya.

\footnotetext{
${ }^{15}$ Wawancara dengan Mujella, Saliman, dan Musallimun (keturunan Kamsidin dari garis Suki yang merupakan anak kedua Kamsidin) di Madura, tanggal 6 Juli 2016.

16Wawancara dengan Mujella, Saliman, Musallimun, dan Mulyati (keturunan Kamsidin dari garis Suki yang merupakan anak kedua Kamsidin) di Madura, tanggal 6 Juli 2016.
} 


\begin{tabular}{|l|l|l|}
\hline NO. & $\begin{array}{l}\text { PERNIKAHAN KEKERABATAN BANI } \\
\text { KAMSIDIN }\end{array}$ & JUMLAH \\
\hline 1. & Perjodohan kekerabatan yang terjadi & 15 \\
\hline 2. & Perjodohan kekerabatan yang berhasil & 12 \\
\hline 3. & Perjodohan kekerabatan yang gagal & 3 \\
\hline 4. & Pernikahan kekerabatan tanpa perjodohan & 9 \\
\hline 5. & Pernikahan kekerabatan yang terjadi & 2317 \\
\hline 6. & Pernikahan kekerabatan yang berhasil & 13 \\
\hline 7. & Pernikahan kekerabatan yang gagal & 10 \\
\hline 8. & Pernikahan kekerabatan rujuk kembali & 1 \\
\hline 9. & Penolak Pernikahan Kekerabatan & 2 \\
\hline
\end{tabular}

Berdasarkan pada penelitian yang telah dilakukan, pernikahan ini dapat diklasifikasikan ke dalam tiga periode. Pertama, periode inti Bani Kamsidin. Kedua, periode penyatuan keluarga. Ketiga periode konflik.

Periode inti Bani Kamsidin merupakan periode yang mana Bani Kamsidin melakukan pernikahan kekerabatan dengan sesama keturunan Kamsidin. Periode ini diawali dengan perjodohan yang dilakukan Kamsidin dan Sardimah terhadap cucu-cucunya. Periode ini terjadi dari tahun 1974 sampai 2015. Kurun waktu yang panjang tersebut dapat dibagi lagi menjadi empat bagian. Pertama, pada tahun 1974. Kedua, pada tahun 1992. Ketiga, pada tahun 2000 dan 2002. Keempat, pada tahun 2015. Pembagian ini dilakukan karena pernikahan inti Bani Kamsidin terhenti dalam beberapa tahun tertentu. Pertama, tahun 1975 sampai 1991. Kedua, tahun 1993 sampai 1996. Ketiga, 2003 sampai 2014.

Bani Kamsidin dalam periode ini melakukan pernikahan kekerabatan dengan pasangan hidupnya yang berasal dari keluarga inti Bani Kamsidin. Hal ini dalam antropologi, Bani Kamsidin termasuk kelompok keluarga besar yang menerapkan pernikahan endogami yang merupakan salah satu pola pernikahan yang digunakan oleh kelompok tertentu. Misalnya pernikahan endogami pada komunitas Arab Alawiyyun kota Pontianak, pernikahan endogami yang diikuti oleh suku Dayak Iban di Kalimantan,

\footnotetext{
17Jumlah pernikahan kekerabatan yang terjadi sudah termasuk pernikahan kekerabatan tanpa perjodohan. Selain itu, beberapa keturunan Kamsidin ada yang melakukan pernikahan kekerabatan sampai dua kali. Mislanya, Muwiyeh, Muhwiyeh, dan Ridwan.
} 
pernikahan endogami yang dilakukan oleh masyarakat Donggo di Sumbawa Timur, dan sebagainya.

Pada periode inti ini, terbagi menjadi dua bagian pernikahan endogami. Pertama, pernikahan endogami yang dilakukan keturunan Kamsidin dengan sepupunya sendiri. Misalnya, Mujella dan Muwillah, Musawi dan Muhwiyah, serta Mushoffa dan Mujibah. Kedua, pernikahan endogami yang dilakukan keturunan Kamsidin dengan keponakannya sendiri atau anak dari sepupunya. Misalnya, Abdul Qodir dan Satuah serta Muhammadun dan Masriyah.

Pada periode penyatuan keluarga, Bani Kamsidin tetap menyelenggarakan melakukan pernikahan kekerabatan, tetapi tidak lagi dengan kalangan keluarga inti melainkan dengan keluarga yang memiliki hubungan kekerabatan dengan mereka. Pernikahan kekerabatan inti Bani Kamsidin beberapa tahun mengalami kesulitan untuk dilakukan karena adanya kendala yang sama seperti yang sudah dijelaskan pada sub bab sebelumnya, yaitu jumlah cucu laki-laki dan cucu perempuan Kamsidin yang tidak seimbang. Oleh karena itu, Bani Kamsidin melakukan pernikahan kekerabatan penyatuan keluarga.

Pernikahan kekerabatan yang dilakukan dengan menikahi calon mempelai dari keluarga yang memiliki hubungan kekerabatan dengan Bani Kamsidin bertujuan untuk menyatukan keluarga tersebut dengan mereka. Pernikahan ini membuat kekerabatan tetap terjaga sehingga tetap utuh. Dengan demikian, kerabat dari Bani Kamsidin tidak menjadi jauh, bahkan semakin dekat. 18

Periode penyatuan keluarga Bani Kamsidin terjadi dari tahun 1975 sampai tahun 2014. Periode ini dibagi menjadi tiga bagian seperti yang telah dipaparkan pada sub bab sebelumnya. Pertama, tahun 1975 sampai 1991. Kedua, tahun 1993 sampai 1996. Ketiga, 2003 sampai 2014.

Pada periode ini terlaksana 18 pernikahan kekerabatan penyatuan keluarga. Namun demikian, di dalamnya juga terjadi pernikahan non kekerabatan atau eksogami. Selain itu, juga terdapat beberapa keturunan keturunan Kamsidin yang menikah beberapa kali, bahkan menikah dengan orang luar dan orang dalam.

Motivasi pokok pernikahan endogami Bani Kamsidin adalah kekerabatan. Memang terdapat sangsi sosial yang menjadikan pelaku

${ }^{18}$ Wawancara dengan Mujella (cucu Kamsidin dari anak yang ketiga yaitu Suki) melalui telepon di Madura, tanggal 11 Oktober 2016. 
pernikahan dengan orang luar jauh dari Bani Kamsidin. Akan tetapi, sangsi sosial memiliki waktu tempo. Hal tersebut dapat terjadi jika pelaku pernikahan dengan orang luar kemudian menikah dengan keturunan Kamsidin atau yang memiliki hubungan kekerabatan dengan Bani Kamsidin serta anak-anaknya melanjutkan pernikahan kekerabatan.

Periode konflik ditandai dengan adanya ketegangan di antara Bani Kamsidin pada tahun 2012. ${ }^{19}$ Pada tahun 2012 ketegangan terjadi karena perjodohan yang gagal antara Halili dan Siti Zya Ama dan kegagalan dalam pernikahan antara Sumar dan Nur Asizah. ${ }^{20}$ Perjodohan antara Halili dan Siti Zya Ama termasuk perjodohan untuk penyatuan keluarga dengan Bani Kamsidin. Siti Zya Ama merupakan cicit Kamsidin yang tidak lain adalah anak Saliman dan Sulaiha Nimah. Adapun Halili adalah anak Juma'i yang tidak lain adalah adik kandung Sum'a. ${ }^{21}$ Perjodohan antara Halili dan Siti Zya Ama terjadi karena adanya kesepakatan Sum'a dan Juma'i pada tahun 2010.22

Perjodohan Sumar dan Nur Asizah sebenarnya lebih dulu dari perjodohan Halili dan Siti Zya Ama. Sumar dan Nur Asizah menikah pada tahun 2011. ${ }^{23}$ Sumar merupakan cicit Kamsidin dari anak yang ketiga yaitu Suki atau anak dari Jalis dan Suhibah. ${ }^{24}$ Nur Asizah adalah adik kandung Halili. ${ }^{25}$ Setelah satu tahun menikah, pernikahan Sumar dan Nur Asizah gagal yaitu pada tahun 2012. ${ }^{26}$

Pada awalnya perjodohan dan pernikahan yang gagal pada Bani Kamsidin tidak menimbulkan konflik. Namun demikian, berbeda saat perjodohan Siti Zya Ama dan Halili serta pernikahan Sumar dan Nur Asizah gagal. Hal ini dikarenakan, Halili dan Nur Asizah berasal dari keluarga yang sama seperti yang telah dijelaskan di atas. Meraka

\footnotetext{
${ }^{19}$ Ibid.,
}

${ }^{20}$ Ibid.,

${ }^{21}$ Wawancara dengan Saliman (cucu Kamsidin dari anak yang ketiga yaitu Suki) di Madura, tanggal 3 Juli 2016.

22Ibid.,

${ }^{23}$ Arsip tentang Arsip Surat Nikah milik Sumar dan Nor Asizah.

${ }^{24}$ Wawancara dengan Saliman (cucu Kamsidin dari anak yang ketiga yaitu Suki) di Madura, tanggal 3 Juli 2016.

${ }^{25}$ Wawancara dengan Sum'a (istri Suki yang merupakan anak Kamsidin) di Madura, tanggal 3 Juli 2016.

26Wawancara dengan Suhibah (menantu Suki dan Sum'a) di Madura, tanggal 03 Juli 2016. 
adalah anak Juma'i yang tidak lain adalah adik Sum'a yang merupakan istri Suki. 27

Jika perjodohan-perjodohan yang gagal sebelumnya selesai setelah musyawarah secara kekeluargaan Bani Kamsidin. Maka pada perjodohan Halili dan Siti Zya Ama gagal sebelum adanya musyawarah pada Bani Kamsidin. ${ }^{28}$ Hal itu disebabkan, pada tahun 2012 Halili menikah dengan orang di luar Bani Kamsidin dan tidak memiliki hubungan kekerabatan dengan Bani Kamsidin sebelum membatalkan perjodohan yang sudah terjadi antara Halili dengan Siti Zya Ama. Pada mulanya keluarga Halili dan Bani Kamsidin tidak mengetahui jika Halili sudah menikah dengan orang lain. ${ }^{29}$

Sebelum selesai masalah yang terjadi pada Bani Kamsidin akibat kegagalan perjodohan antara Halili dan Siti Zya Ama, pada tahun yang sama pernikahan Sumar dan Nur Asizah juga tidak dapat dipertahankan seperti perjodohan Siti Zya Ama dan Halili. Kegagalan tersebut terjadi karena Nur Asizah sudah tidak bisa bersama dengan Sumar. Perceraian terjadi karena adanya pertengkaran di antara mereka. ${ }^{30}$ Oleh karena itu, keluarga Sumar sudah tidak dapat memaksakan kehendak atas pernikahan anak dan menantunya. ${ }^{31}$

Kegagalan yang terjadi di atas oleh kedua anak Juma'i diketahui Bani Kamsidin bahwa terdapat keterlibatan istri Juma'i yang bernama Nur. Pertama, Nur tidak sengaja memberikan Kartu Keluarga Juma'i kepada Halili. Nur tidak mengetahui bahwa Halili meminjam Kartu Keluarga tersebut untuk mengurus surat pindah untuk membuat Surat Nikah. ${ }^{32}$ Kedua, saat Nur Asizah bertengkar dengan Sumar. Nur meminta anaknya untuk pulang ke Madura, sehingga Nur Asizah pulang ke Madura dan meninggalkan keluarga Sumar di Surabaya tanpa memberi tahu atau izin terlebih dahulu. ${ }^{33}$ Selain itu Juma'i sebagai kepala keluarga memberi perlindungan kepada Nur, Halili,

27Wawancara dengan Saliman (cucu Kamsidin dari anak yang ketiga yaitu Suki) di Madura, tanggal 3 Juli 2016.

${ }^{28}$ Ibid.,

29Ibid.,

${ }^{30}$ Wawancara dengan Muhammadin (cucu Kamsidin dari anak yang ketiga yaitu Suki) di Madura, tanggal 3 Juli 2016.

31Wawancara dengan Suhibah (menantu Suki dan Sum'a) di Madura, tanggal 03 Juli 2016

${ }^{32}$ Wawancara dengan Saliman (cucu Kamsidin dari anak yang ketiga yaitu Suki) di Madura, tanggal 3 Juli 2016.

${ }^{33}$ Wawancara dengan Muhammadin (cucu Kamsidin dari anak yang ketiga yaitu Suki) di Madura, tanggal 3 Juli 2016. 
dan Nur Asizah yang sudah jelas bersalah menurut Bani Kamsidin. Oleh karena itu Bani Kamsidin tidak lagi menganggap keluarga Juma'i sebagai bagian dari Bani Kamsidin, walaupun sebenarnya sudah melakukan perjodohan dan pernikahan kekerabatan untuk penyatuan keluarga dengan Bani Kamsidin. Konflik yang terjadi ini adalah antara keluarga Juma'i dengan Bani Kamsidin. ${ }^{34}$

Selain konflik yang terjadi pada tahun 2010 dan 2012, terdapat pula konflik yang terjadi pada tahun 2016. Konflik tersebut berasal dari kegagalan pernikahan Mushoffa dan Mujibah. Pernikahan Mushoffa dan Mujibah hanya bertahan selama empat bulan. Hal ini terjadi karena Mujibah meminta cerai kepada Mushoffa, karena sudah tidak dapat bersamanya. ${ }^{35}$ Dengan demikian, permintaan Mujibah tersebut memicu konflik antara ia dan ibunya. Pada akhirnya, Mujibah memilih meninggalkan rumah ibu kandungnya dan bercerai dengan Mushoffa serta tinggal di rumah ayah kandungnya. ${ }^{36}$

Adapun motif-motif Bani Kamsidin melakukan pernikahan kekerabatan sebagai berikut:

1. Motif Keyakinan Agama

Bani Kamsidin melakukan pernikahan kekerabatan dan dapat bertahan sampai sekarang karena adanya pesan Kamsidin dan Sardimah. Alasan-alasan yang mendasari pesan mereka mengenai pernikahan kekerabatan adalah faktor yang berasal dari dalam Bani Kamsidin sendiri. Oleh karena itu, Bani Kamsidin terdorong untuk menjalankan pernikahan kekerabatan dan mempertahankannya. Adapun Kamsidin dan Sardimah mengarahkan keturunannya untuk menikah secara kekerabatan dilandasi dengan alasan-alasan kehidupan beragama yang diyakini oleh Kamsidin dan Sardimah. Alasan-alasan yang diyakini oleh keduanya adalah baik untuk keturunannya menurut mereka.

Menurut Kamsidin dan Sardimah, dengan adanya pernikahan kekerabatan pada keturunannya dapat membuat setiap kiriman doa, selametan, dan sedekah yang dilakukan keturunannya, langsung sampai kepada yang ditujukan atau yang dikhususkan. ${ }^{37}$ Mereka meyakini hal itu karena sepasang suami istri yang memiliki ikatan

34Ibid.,

${ }^{35}$ Wawancara dengan Muhammadin (cucu Kamsidin dari anak yang keempat yaitu Moh. Jailani) di Madura, tanggal 24 Agustus 2016.

36Ibid.,

37Wawancara dengan Saliman (cucu Kamsidin dari anak yang ketiga yaitu Suki) melalui telepon di Jakarta, tanggal 30 Mei 2016. 
kekerabatan, memiliki sesepuh yang sama dan kerabat yang sama. ${ }^{38}$ Sepeninggal Kamsidin, Sardimah melanjutkan pernikahan kekerabatan dan mengambil alih kepemimpinan Bani Kamsidin serta mengatur keturunannya dengan menjodoh-jodohkan keturunan yang satu ke keturunan yang lain, misalnya saat Sardimah menjodohkan Abdul Qodir (cucu Sardimah dari Moh. Jailani) dan Satuah (cucu Suki atau anak dari Mujella dan Muwilah). ${ }^{39}$ Menurut Sardimah sama seperti yang diyakini bersama Kamsidin sebelumnya, kalau keturunannya menikah dengan kerabat sendiri, akan lebih mudah untuk keturunannya melakukan selametan ${ }^{40}$ dan mengenang wafat sesepuhnya dalam setiap tahun. ${ }^{41}$

\section{Motif Menjaga Keturunan}

Anak-anak dan menantu-menantu dari Kamsidin dan Sardimah melanjutkan pernikahan kekerabatan dengan menjodohkan anakanaknya dengan kerabat sendiri. Hal ini dilakukan dengan alasan untuk berusaha menjadi pemimpin yang baik untuk Bani Kamsidin seperti yang dilakukan Kamsidin dan Sardimah. Harapan dari anakanak dan menantu-menantu Kamsidin dan Sardimah adalah pernikahan kekerabatan yang sudah ada sejak tahun 1974 dilakukan dapat bertahan dan dilakukan secara turun temurun. Oleh karena itu, mereka menurunkan atau meneruskan wasiat atau pesan Kamsidin dan Sardimah kepada anak dan cucu mereka. ${ }^{42}$

Bani Kamsidin memang menerima syarat yang berisi lima larangan seperti yang telah dijelaskan pada bab sebelumnya. Pada mulanya mereka tidak mengetahui faktor-faktor yang melatarbelakangi Kamsidin memberikan lima syarat tersebut. Namun demikian, dalam menjalankan pernikahan kekerabatan, generasi kedua dari keturunan Kamsidin mencari tahu alasan Kamsidin memberikan lima larangan kepada keturunannya. Bani Kamsidin menindaklanjuti larangan Kamsidin secara medis dan fakta yang

\footnotetext{
38Wawancara dengan Saliman (cucu Kamsidin dari anak yang ketiga yaitu Suki) di Madura, tanggal 6 Juli 2016.

${ }^{39}$ Wawancara dengan Abdul Qodir (cucu kamsidin dari anak yang keempat yaitu Moh. Jailani) melalui voice note WhatsApp di Madura, tanggal 7 Oktober 2016.

${ }^{40}$ Selametan merupakan mendoakan keluarga yang sudah meninggal.

${ }^{41}$ Wawancara dengan Abdul Qodir (cucu kamsidin dari anak yang keempat yaitu Moh. Jailani) melalui voice note WhatsApp di Madura, tanggal 7 Oktober 2016.

${ }^{42}$ Wawancara dengan Sum'a (istri Suki yang merupakan anak ketiga Kamsidin) di Madura, tanggal 6 Juli 2016.
} 
terjadi di masyarakat yang memiliki keterkaitan dengan syarat-syarat yang diberikan Kamsidin.

Setelah mendapatkan jawaban dalam setiap larangan baik secara medis dan fakta yang terjadi pada masyarakat di sekitar Bani Kamsidin, keturunan Kamsidin lebih berhati-hati dalam memilih calon mempelai untuk anak-anaknya. Hal ini dilakukan guna menjaga keturunan Kamsidin dari perilaku yang dilarang agama dan menjaga keselamatan keturunan Kamsidin. Oleh karena itu, Bani Kamsidin terdorong untuk mempertahankan pernikahan kekerabatan. Hal ini dikarenakan memiliki latar belakang keluarga yang jelas dan keturunan dari nenek moyang yang terhindar dari kategori dari lima larangan yang diberikan Kamsidin.

3. Motif Keutuhan Keluarga

Kamsidin dan Sardimah memberi pesan atau wasiat kepada keturunannya untuk melakukan pernikahan kekerabatan adalah demi keutuhan Bani Kamsidin. Oleh karena itu, mereka memerintah keturunannya untuk saling mencari satu sama lain agar tidak ada yang hilang dari Bani Kamsidin dengan cara melakukan pernikahan kekerabatan. ${ }^{43}$ Pada dasarnya Bani Kamsidin tidak mengetahui peristiwa apa yang melatarbelakangi Kamsidin dan Sardimah sehingga memunculkan pernikahan kekerabatan pada keturunannya. Namun demikian, dari perkembangan pernikahan kekerabatan yang bermula dari tahun 1974, Bani Kamsidin dapat melihat bahwa Kamsidin dan Sardimah memberikan perlindungan kepada keturunannya bahkan sepeninggal mereka dengan melakukan perjodohan dan pernikahan kekerabatan pada keturunannya.

Alasan lain Kamsidin dan Sardimah melakukan pernikahan kekerabatan pada keturunannya adalah jika keturunannya menikah dengan orang luar maka akan mudah kejar-kejaran perkataan. ${ }^{44}$ Kejarkejaran di sini adalah saling meneliti perkataan masing-masing untuk dicari kesalahannya dan saling mengemukakan alasan saat dipojokkan dengan permasalahan yang timbul. ${ }^{45}$ Alasan Kamsidin dan Sardimah itu, membuat Bani Kamsidin mulai mengerti bahwa mereka menerapkan pernikahan kekerabatan untuk menyelamatkan

\footnotetext{
43Wawancara dengan Saliman (cucu Kamsidin dari anak yang ketiga yaitu Suki) di Madura, tanggal 6 Juli 2016.

${ }^{44}$ Wawancara dengan Sum'a (istri Suki yang merupakan anak ketiga Kamsidin) di Madura, tanggal 6 Juli 2016.

${ }^{45}$ Wawancara dengan Saliman (cucu Kamsidin dari anak yang ketiga yaitu Suki) melalui grup WhatsApp BANI KAMSIDIN plus, 7 Oktober 2016.
} 
keturunannya dari pertengkaran fisik yang diawali dengan pertengkaran lisan. ${ }^{46}$

Dampak Pernikahan Kekerabatan Bani Kamsidin:

1. Dampak Hukum

Dilihat dari segi hukum, Bani Kamsidin melakukan pelanggaran terhadap dua amanat di negara Indonesia, yaitu pada Undang-undang No. 1 Tahun 1974 pasal 6 ayat (1) dan Kompilasi Hukum Islam (KHI) pasal 17 ayat (2). UU No.1 Tahun 1974 pasal 6 ayat (1) menegaskan bahwa, "Perkawinan harus didasarkan atas persetujuan kedua calon mempelai". Demikian juga dalam Kompilasi Hukum Islam (KHI) pasal 17 ayat (2) menyatakan bahwa, "Bila ternyata perkawinan tidak disetujui oleh salah seorang calon mempelai maka perkawinan itu tidak dapat dilangsungkan". ${ }^{47}$ Dua amanat hukum tersebut bertujuan melindungi calon mempelai, agar tetap memperoleh haknya untuk hidup, tumbuh, dan berkembang serta terlindungi dari perbuatan eksploitasi dan diskriminasi.

\section{Dampak Sosial}

Dilihat dari segi sosial, dengan adanya pernikahan kekerabatan membuat ikatan kekerabatan Bani Kamsidin semakin erat. Sehubungan dengan pesan Kamsidin dan Sardimah mengenai keturunannya yang menikah dengan kerabat sendiri, akan lebih mudah untuk keturunannya melakukan selametan ${ }^{48}$ dan mengenang wafat sesepuhnya dalam setiap tahun. ${ }^{49}$

3. Dampak Kesehatan

Dilihat dari segi kesehatan, sehubungan dengan adanya syarat-syarat yang berisi lima larangan yang harus dihindari oleh Bani Kamsidin. Tepat pada larangan yang keempat dan kelima, yaitu larangan menikah dengan anak dari keluarga atau nenek moyangnya ada yang memiliki penyakit lepra dan ayan. ${ }^{50}$ Bani Kamsidin menjadi terhindar dari dua penyakit tersebut.

${ }^{46}$ Wawancara dengan Sulaiha (cicit tiri Kamsidin dari anak yang ketiga yaitu Suki yang merupakan anak ketiga Kamsidin) di Madura, tanggal 6 Juli 2016.

${ }^{47}$ Ibid., hlm. 98.

48Selametan merupakan mendoakan keluarga yang sudah meninggal.

${ }^{49}$ Wawancara dengan Abdul Qodir (cucu kamsidin dari anak yang keempat yaitu Moh. Jailani) melalui voice note WhatsApp di Madura, tanggal 7 Oktober 2016.

${ }^{50}$ Wawancara dengan Mujella, Saliman, Musallimun, dan Mulyati (keturunan Kamsidin dari garis Suki yang merupakan anak kedua Kamsidin) di Madura, tanggal 6 Juli 2016. 


\section{Dampak Pendidikan}

Dilihat dari segi pendidikan, pernikahan kekerabatan dapat menghambat proses pendidikan dan pembelajaran Bani Kamsidin. Hal itu terbukti dari pendidikan terakhir Bani Kamsidin umumnya adalah sekolah tamat SD, yang minim lulusan SMP dan SMA, bahkan yang berada dibangku kuliah hanya dua orang.

5. Dampak Ekonomi

Dilihat dari segi ekonomi, pernikahan kekerabatan memiliki dampak positif untuk Bani Kamsidin. Di dalam Bani Kamsidin, jika terdapat masalah dari salah satu keluarga, maka musyawarah selalu dikedepankan begitu pula yang berhubungan dengan uang. Bagi Bani Kamsidin, lebih baik meminjam uang dari kerabat sendiri dari pada orang lain.

6. Dampak Psikologi

Dilihat dari segi psikologi, ditinjau dari periode konflik yang sudah terjadi. Penulis menemukan adanya trauma pada keturunan Kamsidin yang mengalami kegagalan khususnya dan keturunan Kamsidin yang belum melakukan pernikahan kekerabatan umumnya. Oleh sebab itu, Bani Kamsidin lebih berhati-hati dalam melanjutkan pernikahan kekerabat.

\section{KESIMPULAN}

Pada dasarnya pernikahan kekerabatan Bani Kamsidin bermula dari pesan Kamsidin dan Sardimah kepada anak-anaknya beserta menantu-menantunya untuk menikahkan anak-anaknya secara kekerabatan atau anak dari anak-anaknya saling dinikahkan. Pesan Kamsidin dan Sardimah tersebut disampaikan secara turun temurun sampai sekarang. Bani Kamsidin melakukan pernikahan kekerabatan pertama kali yaitu pada tahun 1974, yaitu pernikahan Mujella (anak pertama Suki) dan Muwillah (anak ketiga Mujenib). Proses pernikahan kekerabatan Bani Kamsidin yaitu nyabek ocak, serpang, certacer, lamaran, ngalak sabek, akad nikah, resepsi pernikahan, ngirem, tongngebben, dan main ke ponduk.

Perkembangan pernikahan kekerabatan yang dilakukan Bani Kamsidin dari tahun 1974 sampai tahun 2015 dapat dibagi menjadi tiga periode, yaitu periode inti Bani Kamsidin, periode penyatuan keluarga, dan peiode konflik. Pernikahan kekerabatan yang telah dilakukan dari tahun 1974 sampai tahun 2015 oleh Bani Kamsidin, bukan merupakan waktu yang singkat. Mereka dapat mempertahankan pernikahan 
kekerabatan karena adanya dorongan yang berasal dari dalam dan luar Bani Kamsidin. Mulanya Bani Kamsidin melakukan pernikahan kekerabatan atas dorongan keyakinan agama yang diyakini oleh Kamsidin dan Sardimah yang diturunkan secara turun menurun dari anak-anak dan menantu-menantunya. Pada perkembangannya Bani Kamsidin melanjutkan pernikahan kekerabatan adalah untuk menjaga keturunan dan keutuhan keluarga. Selain itu, pernikahan kekerabatan memberikan dampak kepada Bani Kamsidin, meliputi dampak hukum, sosial, kesehatan, pendidikan, ekonomi, dan psikologi.

Abdurrahman, Dudung. Metode Penelitian Sejarah Islam. Yogyakarta: Penerbit Ombak, 2011.

Direktorat Jenderal Pembinaan Kesehatan Masyarakat. Pedoman Pelaksanaan: Stimulasi, Deteksi, dan Intervensi Dini Tumbuh Kembang Anak ditingkat Pelayanan Kesehatan Dasar. Jakarta: Kementerian Kesehatan RI, 2012.

Gottshcalk, Louis. Mengerti Sejarah, terj. Nugroho Notosusanto, cetakan ke-3. Jakarta: UI- Press, 1983.

Handoko, Martin. Motivasi Daya Penggerak Tingkah Laku. Yogyakarta, Kanisius, 1992.

Kartono, Kartini. Pengantar Metodologi Riset Sosial, cetakan ke-7. Bandung: Mandar Maju, 1996.

Kartonodirdjo, Sartono. Pendekatan Ilmu Sosial dalam Metodologi Sejarah. Jakarta: Gramedia Pustaka Utama, 1992.

Khuta, Nyoman Ratna. Metode penelitian: Kajian Budaya dan Ilmu Sosial Humaniora Pada Umumnya. Yogyakarta: Pustaka Pelajar, 2010.

Kuntowijoyo. Metodologi Sejarah. Jakarta: Tiara Wacana, 1944.

Pengantar Ilmu Sejarah. Yogyakarta: Tiara Wacana, 2013.

Mardalis. Metode Penelitian, cetakan ke-3. Jakarta: Bumi Aksara, 1995.

Nasution, Khoiruddin. Hukum Perkawinan 1. Yogyakarta: ACAdeMIA + TAZZAFA, 2005. 
Nawawi, Hadari, Metode Penelitian Bidang Sosial. Yogyakarta: Gadjah Mada University Press, 1998.

P. Siagian, Sondang. Teori Motivasi dan Aplikasinya, cetakan ke-4. Jakarta: PT. Rineka Cipta, 2004.

Poerwadarminta. W.J.S. Kamus Umum Bahasa Indonesia, cetakan ke-11. Jakarta: PT Balai Pustaka, 2011.

Pujileksono, Sugeng. Pengantar Antropologi, cetakan ke-2. Malang: UMM Press, 2019. . Pengantar Antropologi. Malang: Intrans Publishing, 2015.

Siregar, Hamka. Ringkasan Disertasi: Pernikahan Endogami Pada Komunitas Arab Alawiyyun Kota Pontianak. Yogyakarta: UIN Sunan Kalijaga, 2009.

Vredenbegh, Jacob. Metode dan Teknik Penelitian Masyarakat, cetakan ke-3. Jakarta: PT. Gramedia, 1938.

Wiyata, A. Latief. Carok. Yogyakarta: LKiS, 2002.

Wawancara:

Wawancara dengan Abdul Qodir (cucu Kamsidin dari anak yang keempat yaitu Moh. Jailani) melalui voice note WhatsApp di Madura, tanggal 7 Oktober 2016.

Wawancara dengan Achmad Abdul Aziz (cucu Kamsidin dari anak yang kedua yaitu Mujenib) di Madura, tanggal 1 Juli 2016 dan 7 Oktober 2016.

Wawancara dengan Achmad Abdul Aziz (cucu Kamsidin dari anak yang kedua yaitu Mujenib) melalui telepon di Madura, tanggal 7 Oktober 2016.

Wawancara dengan Ahmad (suami Morani yang merupakan cucu Kamsidin dari anak yang kedua yaitu Mujenib) di Madura, tanggal 10 Juli 2016.

Wawancara dengan Insyiroh (canggah Kamsidin dari anak kedua dan ketiga yaitu Mujenib dan Suki) melalui telepon di Jakarta, tanggal 30 Mei 2016.

Wawancara dengan Mahmud (cucu Kamsidin dari anak yang kedua yaitu Mujenib) di Madura, tanggal 5 Juli 2016. 
Wawancara dengan Masriah (cucu Kamsidin dari anak yang kedua yaitu Mujenib) di Madura, tanggal 5 Juli 2016 dan 10 Juli 2016.

Wawancara dengan Masriah, Rohayati, dan Muwilah (keturunan Kamsidin dari garis Mujenib yaitu anak kedua Kamsidin) di Madura, tanggal 10 Juli 2016.

Wawancara dengan Mochamad Rido'i (cucu Kamsidin dari anak yang kedua yaitu Mujenib) melalui telepon di Mojokerto, tanggal 5 Juli 2016.

Wawancara dengan Moh. Fathor Rosi (cicit Kamsidin dari anak yang kedua yaitu Mujenib) melalui voice note WhatsApp di Surabaya, tanggal 11 Oktober 2016.

Wawancara dengan Morani (cucu Kamsidin dari anak yang kedua yaitu Mujenib) di Madura, tanggal 6 Juli 2016.

Wawancara dengan Muhammadin (cucu Kamsidin dari anak yang ketiga yaitu Suki) melalui telepon di Madura, tanggal 30 Mei 2016 dan 3 Mei 2016.

Wawancara dengan Muhammadun (cucu Kamsidin dari anak yang ketiga yaitu Suki) melalui voice note WhatsApp di Saudi Arabia, tanggal 9 Oktober 2016 dan 10 Oktober 2016.

Wawancara dengan Muhwiyah (cucu Kamsidin dari anak yang keempat yaitu Moh. Jailani) di Madura, tanggal 24 Agustus 2016.

Wawancara dengan Mujella (cucu Kamsidin dari anak yang ketiga yaitu Suki) di Madura dan melalui telepon, tanggal 1 Juli 2016, 6 Juli 2016, 7 Oktober 2016, dan 11 Oktober 2016.

Wawancara dengan Mujella, Saliman, Musallimun, dan Mulyati (keturunan Kamsidin dari garis Suki yang merupakan anak kedua Kamsidin) di Madura, tanggal 6 Juli 2016.

Wawancara dengan Mulyati (cicit Kamsidin dan merupakan anak dari Mulyaki dan Nur Hayati), tanggal 7 Oktober 2016.

Wawancara dengan Musallimun (cucu Kamsidin dari anak yang ketiga yaitu Suki) di Madura, tanggal 1 Juli 2016 dan 3 Juli 2016.

Wawancara dengan Musawi (cucu Kamsidin dari anak yang ketiga yaitu Suki) di Madura, tanggal 24 Agustus 2016. 
Wawancara dengan Muzaki (cucu Kamsidin dari anak yang kedua yaitu Mujenib) di Madura, tanggal 5 Juli 2016 dan 10 Juli 2016.

Wawancara dengan Muzaki dan Achmad (cucu Kamsidin dari anak yang kedua yaitu Mujenib) di Madura, tanggal 5 Juli 2016.

Wawancara dengan Muzaki dan Masriah (cucu Kamsidin dari anak yang kedua yaitu Mujenib) di Madura, tanggal 10 Juli 2016.

Wawancara dengan Muzaki, Masriah, Rohayati, Muwilah, dan Ahmad (keturunan Kamsidin dari garis Mujenib yaitu anak kedua Kamsidin) di Madura, tanggal 10 Juli 2016.

Wawancara dengan Ridwan (cucu Kamsidin dari anak yang kedua yaitu Mujenib) melalui telepon di Bali, tanggal 5 Juli 2016.

Wawancara dengan Suhibah (istri Jalis atau menantu Suki dan Sum'a) melalui telepon di Surabaya, tanggal 11 Oktober 2016.

Wawancara dengan Saliman (cucu Kamsidin dari anak yang ketiga yaitu Suki) melalui telepon di Jakarta dan secara langsung di Madura, tanggal 16 Maret 2016, 25 Maret 2016, 30 Mei 2016, 3 Juli 2016, 5 Juli 2016, 6 Juli 2016, 7 Oktober 2016, dan 10 Oktober 2016.

Wawancara dengan Sulaiha (cicit tiri Kamsidin dari anak yang ketiga yaitu Suki yang merupakan anak ketiga Kamsidin) di Madura, tanggal 6 Juli 2016.

Wawancara dengan Sum'a (istri Suki yang merupakan anak ketiga Kamsidin) melalui telepon di Madura, tanggal 30 Mei 2016,3 Juli 2016, 6 Juli 2016, dan 10 Oktober 2016. 